\title{
Analysis for Employment Preference of Undergraduate Accounting Students in Oman
}

\author{
Shariq Mohammed \\ Department of Accounting, College of Commerce and Business Administration, \\ Dhofar University, Salalah, Sultanate of Oman
}

\begin{abstract}
The sole purpose of this study was to study the relative importance of different employment factors which affect the students' choice for employment. In this study the factors that affect the choice of employability was studied. This was conducted among the undergraduate accounting students of the University. The factor analysis was done by using the principal component extraction method. The Varimax rotation extraction was used. This gave us three factors that explained $\mathbf{5 7 . 5 9 3}$ percent of the variance. In this study, the following factor was significant as per the factor analysis, which was named as a financial outcome. The variables were starting salary, ability to work independently and future prospects. According to this study, we can see the most important variables that were identified with the help of factor analysis, which were good income and accounting knowledge, starting salary, the ability to work independently, future prospects, and employer's reputation, which accounted for the cumulative contribution rate that reached $57.593 \%$.
\end{abstract}

Keywords - Accounting graduates, employability skills, employment factors, job selection preferences, Factor analysis, Oman.

DOI: 10.18421/TEM102-41

https://doi.org/10.18421/TEM102-41

Corresponding author: Shariq Mohammed, Department of Accounting, College of Commerce and Business Administration, Dhofar University, Salalah, Sultanate of Oman.

Email: shariqmohd2008@yahoo.com, smohammed@du.edu.om

Received: 17 December 2020.

Revised: 29 March 2021.

Accepted: 04 April 2021.

Published: 27 May 2021.

(cc) BY-NC-ND (C) 2021 Shariq Mohammed; published by UIKTEN. This work is licensed under the Creative Commons Attribution-NonCommercial-NoDerivs 4.0 License.

The article is published with Open Access at www.temjournal.com

\section{Introduction}

One of the important tasks in our Omani Universities is enhancing the graduate employability skills. The importance of education is increasing day by day therefore we do not only need theoretical knowledge for the students, but practical knowledge in order to enhance competitive advantages of graduates coming out of the universities.

The accounting subject includes the study of business transaction recording. In selecting an accounting career/job, students should be aware of what is offered by accounting subject. They pointed that the accounting career is usually different from the actual business, so students will have a good idea of that career before choosing it [1].

The Expectancy Theory was developed by Vroom [2]; this theory explains why the individuals choose one behavior over others. It assumes that firstly, the people who join organization have some expectations. Secondly, it is assumed that the behavior is based on certain apprehensions, and therefore people are free to choose the behavior. The next assumption is the expectations of individual are different for different people, therefore some people have expectation for good salary, others have job security, another can have job satisfaction etc. The people will choose from the existing options available, and they will choose the best from the available options. In this research paper, the expectancy theory has been applied to study of accounting students employment options. Employability refers to the employment opportunities, which can be enhanced with the competencies and abilities of the graduates in the labour market [3]. Higher education has been recognized as a channel to enhance the job options. [4], [5].

This research was to study the factors that influenced the employability of university students after graduation. The researcher studied seventeen variables to find out the factors, which influence the employability of the students [6].

In the present day's the higher education's institutes are facing increased pressures to equip the students with the right kind of attributes for the 
potential employers. In this research the researcher examined the various graduate attributes which were important. The research concluded that the communication, creativity, critical thinking, time management, team work, and problem solving were found to be important for the employability [7].

A career is a long-term affair; it is an affair, which is for the lifetime. Therefore, it is very important for a person to select a proper career and employment where he is suited the most. Job selection is an important point which was considered by the researcher [8].

Job security is another criterion for selection of a career [9].Various factors were studied in different researches, andit is concluded that culture, ethnographic, demographic, status or application are the various factors which effect the choice of

accounting career. The choice of any career depends on the variables that determine the student's career selection process. According to the various studies it has been found that there are three basic things which affect the choice of the subject specialization i.e. environment, opportunity (job prospects), and personality influence of family members and peers. All these factors played varying roles in career outcomes [10].

In this paper the researcher studied two groups of students; in which one group wanted to be public accountants, whereas the other group was not interested in the profession. It was inferred that the perception, expectation and opportunities are the factors that helps to finalize the profession after graduation [8].

\section{Literature Review}

In their paper they studied accounting as a profession. This study was conducted in Malaysia to evaluate whether accounting students prefer to become accountants or not. The perception of the undergraduate students was studied with the help of 1000 questionnaires being distributed among them. The starting salary is an important criterion for the selection of career. It was deduced that the university had provided the graduates adequate knowledge for joining the accounting profession [12].

The research was to study the career choices with different nationalities at University of Pretoria. Here various factors related to CA profession were studied including frame of career, students' background, and other job related variables. It inferred that most of the respondents attributed the choice of career in the performance of the grades from 8 to 11 . The major constraint in the selection of the career was the cost of course and qualifying difficulty [13].
This study took place in Japan on the accounting students. The main reason of this study was to study the variables that affected the accounting schools in Japan on the Certified Public Accountant (CPA). It was concluded that the students who studied accounting and business were interested in becoming CPA, whereas other stream of students were not interested in becoming Certified Public Accountant (CPA)[14].

This study was carried out in the Australian higher education sector, where it discussed alternative sources of evidence to study. It was named Graduate Employability Indicators (GEI). Their finding were that the Graduate Employability Indicators (GEI) was required among the all the stakeholders. The results were that if the assessment tasks were changed around authentic tasks, then the accounting graduates would achieve more secure employment, and they would be more successful in choosing the occupations. This would help to benefit themselves, workforce and the community as well as the economy [15].

In this paper, they studied the various academic factors on graduate employability in Nigeria, and they concluded that the academic achievement significantly influenced graduate employability and the curriculum should be aligned [16].

Adrian, $M$ tried to evaluate the skill gap based on the perception of student as compared to the expectation of the employers. The research was on a disciple of business management. It was concluded that the students were underestimating the importance of soft skills, but the employers as well as students were showed a strong expectations of soft skills [3].

This study was conducted in Malaysia where 306 questionnaires were collected. The study was based on the variables, which influenced the career path of students. According to this study, it was concluded that there were factors like instinct motivation, career exposure that influenced the undergraduate accounting students [17].

In their study they discussed about the university's graduate attributes for psychology, nursing and education. In the three disciples, the job searchers said that the employers are searching skill such like communication, cultural understanding and attitudes [18].

This study was conducted among the students of STIE Perbanas Surabaya, it was concluded that the financial rewards, professional recognition and job market conditions influenced the choice of accounting profession; the perception of the personality did not affect the choice of profession [19]. 


\section{Research Methodology}

\section{Research Design}

In this research, descriptive design method was adopted. This study is to assess the relative importance of different employment factors affecting students' employment choices. The factors, which affect the choice of employability among the students of undergraduate students of the University, were studied. The data was collected from the accounting students enrolled at the university. The survey was done among 100 students of the accounting department; they analyzed students' perceptions on their employment choice factors and their importance. Here descriptive study was used to quantify data. The result from target population was generalized based on the sample.

\section{Need for Study / Significant of the Study}

In this research, the researcher has studied the students of accounting specialization. The factors, which affect the choice of employability among the students of undergraduate students of the University, are presented. Various elements were included in this study. Questions included some questions related to the demographic factors of the students. (age, gender, marital status, the year of study, sector planned to work, years of students studying, and educational qualification of the parents). The next part of the questionnaire was based on the factors, which were related to the factors necessary for the employment. The scale indicated one as strongly disagrees and five as strongly agree. Initially there were 17 questions, which were asked in the questionnaire, but due to the Measures of Sampling Adequacy (MSA), six variables were ignored in the factors analysis.

\section{Instruments:}

In this factor, analysis was used to reduce the variables by the rotated method. In this, there were 10 continuous factors, which were reduced to three variables or factors. In the questionnaire, there were The study had two specific objectives, which are as follows.

i) To study various factors affecting accounting student's preference of employment.

ii) To study various sectors of employment the accounting students are interested in pursuing

five general information questions and 16questions, which were based on 5-pointLikert scale.

\section{Data Analysis}

The factor analysis inferred was conducted with the help of SPSS. The version used in the analysis was ver. 16 used for data analysis. We used the data reduction techniques for the analysis in this study. A strong correlation is required in the original variables as to use the data for factor analysis. We can conclude that the data is suitable for the factor analysis. Here we have used principal component analysis method.

Table 1. Demographic profile of the respondents

\begin{tabular}{|c|c|c|c|c|c|}
\hline Gender & $\mathrm{N}$ & $\%$ & \multicolumn{2}{|c|}{ Sector Planned to Work } & \multirow[b]{2}{*}{$\%$} \\
\hline Male & 56 & 56 & & $\mathrm{~N}$ & \\
\hline Female & 44 & 44 & Public Sector & 62 & 62.0 \\
\hline Age & & & Private Sector & 38 & 38.0 \\
\hline $\begin{array}{c}\text { Below } 25 \\
\text { yrs. }\end{array}$ & 36 & 36 & Marital Status & & \\
\hline $26-35$ & 32 & 32 & Married & 34 & 34.0 \\
\hline $36-45$ & 22 & 22 & Unmarried & 66 & 66.0 \\
\hline Above 45 & 10 & 10 & & & \\
\hline \multicolumn{3}{|c|}{ Parents Educational Qualification } & \multicolumn{2}{|c|}{ level of study } & \\
\hline $\begin{array}{l}\text { Secondary } \\
\text { school }\end{array}$ & 20 & 20.0 & 1 st yr. & 7 & 7.0 \\
\hline diploma & 30 & 30.0 & 2nd yr. & 9 & 9.0 \\
\hline Graduation & 32 & 32.0 & 3rd yr. & 39 & 39.0 \\
\hline Masters & 16 & 16.0 & final yr. & 45 & 45.0 \\
\hline Ph.D. & 2 & 2.0 & & & \\
\hline
\end{tabular}

In the above Table 1 out of the total respondents, $56 \%$ were males and $44 \%$ were females. Majority of the respondents were less than 25 years of age, after that $32 \%$ were between 26 to 35 years of age. $22 \%$ respondents were in the age group of 36-45 years, and $10 \%$ were above 45 years of age. Here it is to be noted that the students of 2 nd generation is studying here. We can come across instances when the parents and their wards are completing graduation in the same academic year.

It is observed that most of the respondents want to work for the public sector, which amounts to $62 \%$ whereas only $38 \%$ of respondents want to work for the private sector. It can be observed that most of the respondents want to work for a public sector. 
Here they are more interested in the public sector as there are many opportunities available here. 66\% were unmarried, whereas $34 \%$ were married in the responses from the respondents.

The majority of the respondents were from their final year of studies which amounted to $45 \%$, after that the respondents were from the 3rd year of their study. The majority of the respondents' parents were graduates, after that most of the respondent's parent's had a diploma qualification.

The correlation matrix's was created with the help of 11 variables. These variables were taken from the questionnaire. These variables were in the 5pointLikert scale. We have taken all 11variables to find out the significance levels of bivariate correlation. We observe that all the variable were significant in the correlation table. For applying the factors analysis one of the important prerequisite is to see the significance between the variables. This is used to measure adequacy, in order to see that the data is adequate.

In the Table 3 we can see that the starting salary and employer's reputation represent that future prospects have the highest average/mean among all the given factors.
In the Table 2the Kaiser-Meyer-Olkin (KMO) and Bartlett's Test are given. The Kaiser-Meyer-Olkin (KMO) Value is 0.659 and Bartlett sphericity test value is 184.344 , therefore the original data is fit for factor analysis. The measure of adequacy is desirable for the Factor analysis.

Table 2. KMO and Bartlett's Test

\begin{tabular}{|c|c|c|}
\hline \multicolumn{2}{|c|}{$\begin{array}{c}\text { Kaiser-Meyer-Olkin Measure of Sampling } \\
\text { Adequacy. }\end{array}$} & 659 \\
\hline $\begin{array}{l}\text { Bartlett's Test of } \\
\text { Sphericity }\end{array}$ & $\begin{array}{c}\text { Approx. Chi-Square } \\
\text { df }\end{array}$ & $\begin{array}{c}184.344 \\
45\end{array}$ \\
\hline & Sig. & .000 \\
\hline
\end{tabular}

Correlation is always high but anti image correlation is less. Measures of sampling adequacy should always be more than 0.5 in the principal diagonal of Anti-image Correlation. The principal diagonal should be more than 0.05 .

Table 3. Descriptive Statistics

\begin{tabular}{|l|c|c|c|}
\hline & Mean & Std. Deviation & Analysis N \\
\hline Ability to work independently & 3.50 & .927 & 100 \\
Accounting Knowledge /subject knowledge & 3.62 & 1.042 & 100 \\
social status & 2.58 & .966 & 100 \\
Starting Salary & 4.20 & .853 & 100 \\
Excellent Computing and Related Skills & 3.18 & .914 & 100 \\
employers reputation & 4.20 & .778 & 100 \\
Interest in accounting profession & 3.76 & .976 & 100 \\
good income & 3.02 & .953 & 100 \\
future prospects & 4.16 & .861 & 100 \\
Opportunity to gain experience & 3.72 & .854 & 100 \\
\hline
\end{tabular}


Table 4. Total Variance Explained

\begin{tabular}{|c|c|c|c|c|c|c|c|c|c|}
\hline \multirow{2}{*}{ Component } & \multicolumn{3}{|c|}{ Initial Eigen values } & \multicolumn{3}{c|}{$\begin{array}{c}\text { Extraction Sums of Squared } \\
\text { Loadings }\end{array}$} & \multicolumn{3}{c|}{$\begin{array}{c}\text { Rotation Sums of Squared } \\
\text { Loadings }\end{array}$} \\
\cline { 2 - 9 } & Total & $\begin{array}{c}\text { \% of } \\
\text { Variance }\end{array}$ & Cumulative \% & Total & $\begin{array}{c}\text { \% of } \\
\text { Variance }\end{array}$ & Cumulative \% & Total & $\begin{array}{c}\text { \% of } \\
\text { Variance }\end{array}$ & $\begin{array}{c}\text { Cumulative } \\
\%\end{array}$ \\
\hline 1 & 2.291 & 22.907 & 22.907 & 2.291 & 22.907 & 22.907 & 2.154 & 21.540 & 21.540 \\
2 & 2.174 & 21.740 & 44.647 & 2.174 & 21.740 & 44.647 & 1.879 & 18.793 & 40.333 \\
3 & 1.295 & 12.946 & 57.593 & 1.295 & 12.946 & 57.593 & 1.726 & 17.260 & 57.593 \\
4 & .926 & 9.263 & 66.856 & & & & & & \\
5 & .750 & 7.498 & 74.354 & & & & & & \\
6 & .677 & 6.771 & 81.125 & & & & & & \\
7 & .590 & 5.904 & 87.028 & & & & & & \\
8 & .483 & 4.827 & 91.855 & & & & & & \\
10 & .420 & 4.195 & 96.051 & & & & & & \\
\end{tabular}

Extraction Method: Principal Component Analysis.

Here we have analyzed the data with the help of SPSS version 16. The data reduction and purification has been used. The insignificant items were deleted. In this factor analysis, three factors were significant which explained 57.593 percent of the variance (Table 4).

\section{Findings:}

Using the factor loadings, the attributes were grouped into their respective factors. The finding of the study has been summarized as follows.

\section{Factor 1}

First factor comprised two items viz., good income and accounting knowledge, which we can name as financial reimbursement. The total variance explained by factor 1 is 21.540 percent.

\section{Factor 2}

This factor comprised three variables viz., starting salary, and ability to work independently, future prospects. The total variance explained by factor 2 is 18.793 percent.

\section{Factor 3}

This factor comprised one variable Viz., employer's reputation. It explained 17.260 percent variance, and it can be labeled as employer's prestige for the employee. The total variance explained shows that Eigen values of the first three components are greater than one and the cumulative contribution rate has reached $57.593 \%$.

The Table 5 showed rotated Component Matrix which has removed the all the crossloading factors and after that it has given all variables which were the first two components were good income and accounting subject Knowledge, the second components were starting salary, ability to work independently and future prospects and the third component was employers reputation. 
Table 5. Rotated Component Matrix ${ }^{a}$

\begin{tabular}{|c|c|c|c|}
\hline & \multicolumn{3}{|c|}{ Component } \\
\hline & 1 & 2 & 3 \\
\hline good income & .766 & .004 & -.226 \\
\hline Accounting Knowledge /subject knowledge & .735 & .064 & .044 \\
\hline social status & .586 & -.374 & .262 \\
\hline Excellent Computing and Related Skills & .564 & .083 & -.067 \\
\hline Starting Salary & -.066 & .836 & -.164 \\
\hline Ability to work independently & .029 & .607 & .546 \\
\hline future prospects & .025 & .602 & .453 \\
\hline Opportunity to gain experience & .445 & .540 & .144 \\
\hline employers reputation & .096 & .075 & .797 \\
\hline Interest in accounting profession & .390 & .041 & -.643 \\
\hline
\end{tabular}

Extraction Method: Principal Component Analysis. Rotation Method: Varimax with Kaiser Normalization.

a. Rotation converged in 8 iterations.

\section{Conclusions and Limitations}

In this research paper the reliability of the data collection instrument need to be calculated, and therefore Measures of Sampling Adequacy (MSA) was checked. It included the correlations, KMO and Bartlett's Test. We can observe that the KMO Value is 0.659 and Bartlett sphericity test value is 184.344 , significance value of 0.00 is far less than the significance level of 0.05 . It was observed that most of the respondents want to work for a public sector undertaking in Oman.

This study was based on the factor analysis to find the important factors, which influence the choice of employability among the students of the University. The students were from the specialization of accounting. The factors, which were significant in the study, were financial outcome, starting salary, ability to work independently, future prospects, good income and accounting knowledge, starting salary, the ability to work independently, future prospects, and employer's reputation.

These finding corroborated with the study conducted which showed that job prospects factors, high earnings, availability of jobs, were the most important factors that influence the career choice among students[20].
In this study, it was surmise that the students preferred large sized employers to medium. Small size employers and good salaries was another factor in this study which match the findings of good salary and employer's reputation [21].

This study discussed the concept of self-regulated learning and the factors that contribute to the adequate application of self-regulating strategies [11].

In some of the studies, the student's choice had an association with the financial outcome and the future job opportunities.

In this study, the factor of financial outcome as well as starting salary, ability to work independently, and future prospects were some of the factors, which were the outcome of the factor analysis.

According to this study we can see the most important variables which were identified with the help of factor analysis, and they were good income and accounting knowledge, starting salary, ability to work independently, future prospects and employer's reputation which accounted for the cumulative contribution rate which reached $57.593 \%$.

Talking about limitations of the study, there were two limitations of this study, which were the sample size of the students, which was only 100 and that the second limitation was that they were taken only from the city of Salalah. The results could not be generalized. The further scope of the research is that more cities and more respondents' of different universities and cities can be taken into consideration for further elaboration. 


\section{References}

[1]. Ghani, E. K., Said, J., Nasir, N. M., \& Jusoff, K. (2008). The 21 st century accounting career from the perspective of the Malaysian university students. Asian Social Science, 4(8), 73-83.

[2]. Vroom, V. H. (1964). Work And Motivation. San Francisco, CA: Jossey-Bass.

[3]. Jeswani, S. (2016). Assessment of Employability Skills Among Fresh Engineering Graduates: A Structural Equation Modeling Approach. The IUP Journal of Soft Skills, 10(2), 7-43.

[4]. Adrian, M. (2017). Determining the skills gap for new hires in management: Student perceptions vs employer expectations. International Journal for Innovation Education and Research, 5(6), 139-47.

[5]. Hooley, T. (2017). Climbing the employability mountain. Graduate Market Trends.

[6]. Finch, D. J., Hamilton, L. K., Baldwin, R., \& Zehner, M. (2013). An exploratory study of factors affecting undergraduate employability. Education+ Training, 55(7), 681-704. http://doi.org/10.1108/ET-07-2012-0077

[7]. Osmani, M., Weerakkody, V., \& Hindi, N. (2017). Graduate attributes in higher education: Examining academics' perception in the Middle East. Journal of Education for Business, 92(2), 53-64. doi: $10.1080 / 08832323.2016 .1274713$

[8]. Harnovinsah, H. (2017). Career decision of accounting students and its influencing factors: A study of university accounting students in DKI Jakarta, Indonesia. International Journal of Finance and Accounting, 6(2), 59-65.

[9]. Shivaswamy, M. K., \& Hanks, G. F. (1985). What do accounting students look for in a job. Management Accounting, 66(12), 60-61.

[10]. Segall, M. H., Dasen, P. R., Berry, J. W., \& Poortinga, Y. H. (1999). Human behavior in global perspective.

[11]. Šteh, B., \& Šarić, M. (2020). Enhancing self regulated learning in higher education. Journal of Elementary Education, 13(Spec. Iss.), 129-150.

[12]. Said, J., K Ghani, E., Hashim, A., \& Mohd Nasir, N. (2004). Perceptions towards accounting career among Malaysian undergraduates. National Accounting Research Journal, 2(1), 17-30. https://doi.org/10.1108/19852510480000658
[13]. Myburgh, J. E. (2005). An empirical analysis of career choice factors that influence first-year Accounting students at the University of Pretoria: a cross-racial study. Meditari: Research Journal of the School of Accounting Sciences, 13(2), 35-48.

[14]. Sugahara, S., Hiramatsu, K., \& Boland, G. (2009). The factors influencing accounting school students' career intention to become a Certified Public Accountant in Japan. Asian Review of Accounting, 17(1), 5-22.

[15]. Oliver, B., Whelan, B., Hunt, L., \& Hammer, S. (2011). Accounting graduates and the capabilities that count: Perceptions of graduates, employers and accounting academics in four Australian universities. Journal of Teaching and Learning for Graduate Employability, 2(1), 2-27.

[16]. Edinyang, S. D., Odey, C. O., \& Joseph, G. I. M. B. A. (2015). Academic factors and graduate employability in Nigeria. Global Journal of Human Resource Management, 3(5), 9-17.

[17]. Ng, Y. H., Lai, S. P., Su, Z. P., Yap, J. Y., Teoh, H. Q., \& Lee, H. (2017). Factors influencing accounting students' career paths. Journal of Management Development.

https://doi.org/10.1108/JMD-11-2015-0169

[18]. Oraison, H. M., Konjarski, L., \& Howe, S. T. (2019). Does university prepare students for employment? Alignment between graduate attributes, accreditation requirements and industry employability criteria. Journal of Teaching and Learning for Graduate Employability, 10(1), 173-194.

[19]. Cahyadi, D. D., Andayani, S., \& Suryaningrum, D. H. (2019). Accounting Students Perceptions on Factors Affecting Career Choices. Journal of Accounting and Strategic Finance, 2(2), 170-182.

[20]. Zotorvie, J. S. T. (2016). Determinants of Career Choice among Students of Institute of Chartered Accountants (Ghana). European Scientific Journal, 12(31), 255-274. https://doi.org/10.19044/esj.2016.v12n31p255

[21]. Baliyan, P. S., \& Baliyan, S. P. (2016). Employment Preference of Undergraduate Accounting students in Botswana: Perceptional Analysis of Practitioners and Students. International Journal of Business and Management, 11(12), 271-282. doi: $\underline{10.5539 / \mathrm{ijbm} . v 11 \mathrm{n} 12 \mathrm{p} 271}$ 